\title{
CANCER STEM CELL BIOLOGY
}

\author{
Tieu Lan CHAU, Erta XHAFA, Serkan İsmail GÖKTUNA* \\ Department of Molecular Biology and Genetics, Bilkent University, Ankara, TURKEY \\ *Corresponding author: ORCID ID: orcid.org/0000-0001-6169-768X, e-mail: serkan.goktuna@ bilkent.edu.tr
}

Cite this article as:

Chau T.L, Xhafa E., Göktuna S.İ. 2019. Cancer Stem Cell Biology. Trakya Univ J Nat Sci, 20(Special Issue): S33-S44, DOI: 10.23902/trkjnat.483577

Received: 16 November 2018, Accepted: 20 January 2019, Published: 1 February 2019

\begin{abstract}
Cancer is becoming the leading cause of death all around the world. To develop better therapeutic options against cancer, we need a thorough understanding of tumor development and dissemination. As our knowledge increases, it becomes apparent that cancer is a very complex disease and this complexity is partially due to the great level of heterogeneity even within the same tumor mass. Therefore, there is a pressing need to decipher complex regulations and interactions of the tumor cells that lead to different hierarchies. Concepts of tumor-initiating and self-renewing stem cells have long been proposed to explain the emergence of a vast number of progenies within monoclonal neoplastic growth. It is now known that cancer stem cells which are found in many cancers have many roles in tumor development and dissemination. Many fascinating properties of cancer stem cells draw further attention to clarify their involvement in tumor cell plasticity, epithelial to mesenchymal transition, chemotherapy resistance and to develop therapeutic strategies for their targeting. Here we summarized recent efforts to illustrate the progress in our understanding of the biology of cancer stem cells.
\end{abstract}

Key words: Cancer stem cells, differentiation, plasticity, clonal selection, lineage tracing, and cancer therapy.

Özet: Kanser tüm dünyadaki ölümlerin en önde gelen sebebi olma yolunda ilerlemektedir. Kansere karşı daha etkili tedavi seçenekleri geliştirmek için tümör gelişimi ve yayılmasının çok daha iyi anlaşılması gerekmektedir. Konuyla ilgili bilgilerimiz arttıkça kanserin çok karmaşık bir hastalık olduğu ve bu karmaşıklığın kısmen aynı tümör kitlesinde dahi görülebilen yüksek heterojenlik düzeyine bağlı olduğu ortaya çıkmaktadır. Bu nedenle, farklı hiyerarşilere yol açan tümör hücreleri arasındaki karmaşık düzenleme ve etkileşimlerin açıklığa kavuşturulması için artan bir ihtiyaç söz konusudur. Tümör başlatan ve kendini yenileyen kök hücre kavramları, monoklonal tümör gelişiminde görülen çok sayıdaki neslin ortaya çıkışını açıklamak için uzun zamandan beri ileri sürülmektedirler. Artık günümüzde çoğu kanser tipinde bulunan kanser kök hücrelerinin tümör gelişimi ve yayılmasında çok sayıda rolleri olduğu bilinmektedir. Kanser kök hücrelerinin sahip oldukları pek çok ilginç özellikleri, tümör hücresi plastisitesi, epitemezenkimal dönüşüm ve kemoterapi direncindeki rollerinin açıklığa kavuşturulması ve yeni tedavi stratejilerinin geliştirilmesi için daha da ilgi çekmektedir. Bu çalışmada kanser kök hücresi biyolojisi ile ilgili bildiklerimizde yaşanan gelişmeleri ortaya koyabilmek için yapılan son çalışmalar özetlenmiştir.

\section{Basic definitions: tissue stem cells vs. cancer stem cells}

Stem cells (SCs) are described as having unlimited growth and division potential. They are hence called selfrenewing cells of different adult tissues (Merrell \& Stanger 2016). Although their regenerative potential is not as high as in the case of embryonic SCs (ESCs), tissue SCs can still differentiate into various cell types within a given tissue and therefore considered as being pluripotent (Grompe 2012). SCs are less differentiated relative to their increasingly better differentiated descendants. In contrast to SCs, normal somatic cells usually get arrested in a postmitotic state where they will never return back to cell division cycle (Merrell \& Stanger 2016). In normal tissue hierarchy, SC divisions usually give rise to two daughter cells, one of which remains to be a SC while the other is destined to be differentiated. This type of division is called asymmetrical since it does not yield identical daughter cells in contrast to symmetrical divisions (Morrison \& Kimble
2006). The daughter cell which exits SC state is called progenitor cell or transit-amplifying cell since it still has the ability to continue cell division for a limited period of time. Many tissues, such as stomach, intestine and hair follicles, have examples of such intermediate cells before the emergence of fully differentiated descendants of the SCs (Rangel-Huerta \& Maldonado 2017). Since the progenitors/transit-amplifying cells can continue to divide and form differentiated cells in the tissue, SCs do not need to divide continuously but periodically to generate progenitor cells which are responsible for most of the cell divisions occurring in the tissue (Rangel-Huerta \& Maldonado 2017). By doing so, SCs are protected from mutations and other stressful insults associated with highly proliferative state.

Previously, SCs were thought to be mostly composed of quiescent $\mathrm{SC}$ niches which may be a significant fraction of the cells in different tissues (Clayton et al. 2007). 
However, recent studies have put forward that in some epithelial tissues, like in intestine and stomach, SCs may be actively dividing throughout the life of the organisms (Barker et al. 2007, Barker et al. 2010). SCs also do not necessarily show asymmetric mitotic processing all the time (Batlle \& Clevers 2017). In contrast to the classical view of asymmetric division, SC division may result in cells with different fates due to a process called neutral competition (Leushacke et al. 2013, Snippert et al. 2010, Doupe et al. 2010). The neutral competition occurs due to availability of different niches in the given tissue and may result in all SCs, all differentiated cells or mixed cell populations. The process of neutral competition is highly variable in outcomes yet it depicts great plasticity of SC niches in generating tissues like epidermis, intestine and stomach (Batlle \& Clevers 2017). Overall, all SCs and the resulting daughter cells show great levels of plasticity in which even fully differentiated cells can re-gain stemness (hence called quiescent stem cells) or they may substitute upon loss of stem niche in various tissues ( $\mathrm{Li} \&$ Bhatia 2011). In some extreme cases with highly regenerative tissues like in liver, fully-differentiated hepatocytes can restore the lost tissue without reverting back to SCs (Stanger 2015). In most tissues, with rare exceptions like in hair follicle cells and nerve cells, it is not possible to find a quiescent SC (Hsu et al. 2014, Morizur et al. 2018). Therefore, it seems that nature has evolved diverse ways for tissue maintenance and repair in tissues of different origins even within the same organism.

Current efforts in cancer research have focused on understanding if mechanisms responsible for the tissue organization are functioning similarly in tumors as well. Thus, a similar model has been adopted by researchers trying to identify the interrelations of the cells within a tumor (Weinberg 2013). In this model, the tumorinitiating cells, which have the limitless self-renewal ability to generate vast number of neoplastic progenies are termed as cancer stem cells (CSCs). As we will explore in the following parts in more detail, CSCs are the only cell population in a given tumor which has the ability to initiate the formation of a whole new tumor when transplanted elsewhere or in a new organism (Nassar \& Blanpain 2016). Indeed, surface marker sorted cell transplantation experiments resulted in identification of CSC populations in various cancers (Doulatov et al. 2012, Clevers 2011). Although CSCs and their progeny are genetically identical as in the case of asymmetric cell division in normal tissues, CSCs are the only cells with tumor-initiating and self-renewal potentials. The progeny cells, on the other hand, have lost their tumor-initiating abilities most probably due to being devoid of selfrenewing capacity yet they may still be observed as highly proliferative (analogous to transit amplifying cells) during tumor progression. As our understanding on the cellular mechanisms regulating CSCs increases, it turns out to be more ostensible that these mechanisms are very similar to the ones that operate in normal tissue stem cells (Weinberg 2013). Hence, tumors do not develop new SC programs altogether. Instead they apply the basic rules operating in tissue SCs to adapt to the ever-changing conditions within the tumor microenvironment (Göktuna et al. 2018).

\section{Identifying CSCs from tumors: transplantation vs. lineage-tracing}

\section{Xenotransplantation Experiments}

Tumor progression usually occurs in a multistep manner in which tumor cells progressively acquire mutations leading to novel characteristics so that they can advance from benign to malign during the process. Moreover, not only different tumors from the same patient differ in composition of the cells but also high level of heterogeneity is observed even within the same tumor (Göktuna et al. 2018). All these different cells with different evolutionary history may lead to different cell populations harboring distinct mutations and characteristics (Magee et al. 2012). While some cells are highly proliferating, others can be observed to be senescent or dormant, yet others may be invasive and still others can be apoptotic all within the same tumor mass (Marusyk 2012). Although tumors arise from gradually altered normal tissue cells, many previous efforts to understand the origins of tumor cells have put forward that tumors are usually monoclonal (Novelli et al. 2003). In other words, tumors usually originate from a single ancestor cell which crosses over the border between normal and abnormal growth. The differences among tumor cells happen later on during the tumor development due to the highly mutagenic state of the tumor cells arising from fast proliferation (Nassar \& Blanpain 2016). Especially, a recent report showed that intratumoral diversification occurs at the cellular level in colorectal tumors which have vastly increased their ability to mutate in a series of clonal expansion (Roerink et al. 2018). Clonal succession model is usually ascribed to explanation for this phenomenon. The model states that a mutant tumor cell, originated from the monoclonal tumor mass, may generate a vast number of progenies, and among these progenies, subsequent mutational events will cause additional floods of clonal expansion to generate new tumor subclones (Weinberg 2013). Therefore, the differences that lead to heterogeneity are gained later on during tumor progression.

Surprisingly, further experiments have proven that the cells resulting from a single clone were not always displaying the same characteristics and also not all of them were capable of generating new progenies within the neoplastic growth. In these experiments, human tumor cells were separated into distinct subpopulations via FACS which uses differential expression of various cell surface markers in diverse cell populations (Uçkun et al. 1995). The first experiments were carried out in hematological malignancies due to inherent qualities like less intratumoral heterogeneity and extensive knowledge of hematological cell surface markers. The first cancer where cell sorting utilized was acute myelogenous leukemia (AML) in which cells were sorted according to more or less differentiated phenotypes (Lapidot et al. 
1994). Majority of the sorted cells were granulocytes and monocytes and these cells had very limited ability to proliferate in vivo while less well differentiated $\mathrm{CD} 34^{+} \mathrm{CD} 38^{-}$cells (less than $1 \%$ ) were actively proliferating and were able to form tumors when injected into immuno-compromised nude mice. Hence, only a small fraction of the tumor cells in AML was composed of tumorigenic and self-renewing cells which were later described as CSCs (Lapidot et al. 1994, Bonnet \& Dick 1997). For a long time, similar observations in other hematological malignancies solidified CSC hypothesis. However, in solid tumors, CSCs could not be proven until successful sorting of breast cancer tumors yielded that about $2 \%$ of the cells were CSC $\left(\mathrm{CD} 44^{+} \mathrm{CD} 24^{-/ \mathrm{low}}\right)$ and only 200 of such cells (as opposed to 10.000 cells from the original tumor mass) were sufficient to form tumors in xenotransplant experiments (Al-Hajj et al. 2003). This time, on the contrary, majority vs. minority of the sorted cell populations were showing comparable activity in their cellular growth while they were observed to display great differences in their tumorigenic abilities. Later on, self-renewing CSC subpopulations were demonstrated to be present in many other solid malignancies like hepatocellular, brain, lung, pancreatic, colorectal, head and neck cancers (Enderling et al. 2016, Nassar \& Blanpain 2016). Therefore, results of all these experiments propose that organization of tumor cells shows similarities to normal tissues where minor groups of self-renewing stem cells can generate large number of cells while descendant cells have limited ability to do so. Currently, we also understand that these minority cell populations within tumors express distinct cell surface markers than that of non-SCs which further illustrates that these two cell populations most probably reside at different levels of differentiation.

Accumulating evidence from previous reports suggest that not in all cancers development of tumors were adhering to CSC model. As some critics of xenotransplantation assays reported that mouse leukemia cells, instead of human AML, were transplanted into immunocompetent mice and the CSC frequency was observed to be very high at about $10 \%$ or more (Kelly et al. 2007, Williams et al. 2007). Still other contrasting claims have resulted from serial transplantation experiments in mice. For instance, the percentage of tumor initiating cells in melanoma may vary dramatically depending on the applied technique. CSCs from melanoma samples were previously claimed to be very rare at about one cell in a million (Schatton et al. 2008, Quintana et al. 2008). However, about a quarter of melanoma cells can form tumors in xenotransplantation assays (Boiko et al. 2010). Hence, it is possible to conclude that either melanoma cells do not fit to CSC model or most melanoma cells behave like CSC within tumors (Clevers 2011). Similarly, serial xenograft studies in pancreatic cancer suggested that tumor growth is normally not sustained by CSC but rather by transiently activated tumor initiating cells in pancreatic tumors (Ball et al. 2017). As these examples have suggested, determining minority subpopulations as CSC may not be relevant in all cancers since not all cancers fit to the frequency dependent CSC model. Previous studies with leukemia were only successful due to less intratumoral heterogeneity than in solid cancers. Coupled with extensive knowledge on cell surface antigens, functional differences within genetically homogenous populations of leukemia cells could easily be determined (Clevers 2011). However, most of the cancer cell behaviors and the surface marker expressions in solid tumors were determined due to cell-to-cell and cell-to-ECM interactions within the tumor microenvironment (Batlle \& Clevers 2017). Nevertheless, these inherent differences make it impossible to model such interactions in any transplant experiments. Consequently, due to technical limitations of xenotransplant experiments and the differences in conditions of the microenvironment in spontaneous vs. grafted tumors, these types of approaches were not found to be very effective in identifying CSCs in most cancers.

\section{Lineage-Tracing Experiments}

Analysis of tissues through genetic-lineage tracing become the standard for identifying adult tissue SCs in recent years. In general, lineage tracing allows us to determine SCs in solid tissues within living organisms without disturbing the original tissue. Lineage tracing usually relies on finding a marker gene (like Lgr5 in intestinal SCs) which enables specific expression of an inducible recombinase (like Cre recombinase). The latter helps to facilitate stable activation of a reporter gene (like LacZ, GFP or RFP) in the progeny of a desired cell population which can be further tracked and studied due to continued expression of the reporter gene (Barker \& Clevers 2010, Kretzschmar \& Watt 2012). SC like properties of the progeny cells can be assessed within a given subclone by the use of this approach. In parallel to observations with CSCs, adult SCs behave quite different than transplanted SCs. For instance, in mouse hair follicle SCs, transplanted hair follicle SCs were observed to turn into any epidermal lineages whereas they could only produce hair follicle lineages in lineage tracing experiments (Morris et al. 2004). All these findings collectively support that the transplantation-based approaches are not sufficient to understand the fate and potential of adult SCs in situ (Batlle \& Clevers 2017). Genetic-lineage tracing-based approaches, on the other hand, may be limited due to the availability of SC markers yet they provide unprecedented amount of information about the true characteristics of SCs and their progeny in organizing tissue hierarchy and architecture.

The value of understanding SC characteristics through lineage tracing is not different in tumors. Therefore, many studies recently focused on identifying CSC markers and tracing CSC behaviors in mouse and human models of spontaneous tumor development and dissemination. The first such study was carried out with a mouse model of 
carcinogen induced papilloma, in which SC like clones within tumor were tracked with an inducible basal cell specific Krt14-Cre driver system (Driessen et al. 2012). In this model, most of the label retaining cells disappeared since these cells were terminally differentiated and lost their SC like properties. However, some label retaining cells within traced clones kept surviving and produced large flocks of progeny cells in benign growths. In the same study, mathematical models generated from lineage tracing data demonstrated that CSCs may divide symmetrically or asymmetrically in stochastic patterns to give rise to CSCs or progeny cells in a similar manner to adult tissue SCs within normal epidermis. Moreover, similar observations were made for the identification of intestinal CSCs in a different model of mouse adenoma (Schepers et al. 2012, Kozar et al. 2013). In one study, a mutant floxed Apc gene $\left(\mathrm{Apc}^{\mathrm{fl} / \mathrm{fl}}\right)$ was specifically induced in cells expressing intestinal SC specific Lgr5 marker by the use of Lgr5-EGFP-Ires-cre-ER ${ }^{\mathrm{T} 2}$ knock in allele (coding for a cre recombinase in Lgr5 expressing cells upon tamoxifen induction). Upon activation, Apc mutant cells could be observed through the use of tdTomato (red) fluorescent reporter (Schepers et al. 2012). After these cells initiated the growth of tumor mass, another inducible reporter gene (R26R-Confetti) was activated via tamoxifen injection which turned Lgr5 positive cells into random colors, in one case some of the red Apc mutant cells turned into blue upon tamoxifen induction and later on it was observed that most of the tumor mass was occupied by these blue cells (Schepers et al. 2012). This and similar other experiments provided the support for hierarchical organization of cells within tumors and the presence of only a minor part of Lgr5 expressing neoplastic cells acting as CSCs in intestinal tumors. In a mouse model of breast cancer with MMTV-PyMT, it was shown, by the use of multi-colored lineage tracing via intravital imaging, that some colonies were observed to initially grow but later disappeared while other colonies quickly expanded to become dominant growth within tumors (Zomer et al. 2013). These studies nicely illustrate intratumoral cell dynamics and tumor heterogeneity as well as the presence of CSCs in mouse breast tumors.

Some preliminary transcriptomic studies suggested that human colorectal tumors are also organized into subpopulations as in the case of normal epithelia (MerlosSuarez et al 2011). These studies also provided approaches to analyze CSCs in organoids (Dalerba et al. 2011). Later on, other studies put these principles in application involving patient-derived and CRISPR/Cas9 edited organoids, together they solved the problem with inability to model human cancer for lineage tracing and CSC identification. Similar to mouse experiments, xenografts made up of Lgr5 expressing (stem cell like) organoids were observed to generate large amount of progeny cells for longer time before eventually differentiating while xenografts with differentiation marker expressing (like Krt20) organoids stopped growing and usually disappeared (Cortina et al. 2017, Shimokawa et al. 2017). Therefore, lineage tracing experiments can predict the true nature of CSCs within the tumor microenvironment in both mice and human models of tumorigenesis. These studies also provide strong tools for understanding cancer development and suggesting potential therapeutic applications.

\section{CSC plasticity: Stemness, tumor microenvironment and EMT}

\section{CSCs and Stemness}

Even though most of the tumors arise from a single cell with unlimited proliferative ability, various functions of tumors from tumor initiation to progression and metastasis are all achieved through ability of the tumor cells to differentiate or de-differentiate into other cell niches by the help of tumor cell plasticity (Marusyk et al. 2012, Magee et al. 2012). The great level of plasticity of CSCs is the reason behind their ability to adapt to everchanging and harmful conditions within the tumor microenvironment (Beck \& Blanpain 2013). Heterogeneity within tumors is not only due to cellular plasticity but also their ability to alter tumor microenvironment through complex interaction of various cell types like tumor cells, stromal cells and immune cells (Göktuna et al. 2018). Therefore, we need thorough understanding of mechanisms leading to tumor cell plasticity to fully appreciate CSC behavior in various cancers. The mechanism of plasticity is governed by several factors within the tumors, such as mutability, stemness and trans-differentiation, epithelial to mesenchymal transition (EMT) and creation of an inflammatory microenvironment (Göktuna et al. 2018). All these factors act in a synchronized manner favoring continuous tumor development and metastasis.

Since most CSCs follow the basic rules operated in normal tissues, we start our discussion with plasticity of SCs in normal tissues to understand those mechanisms governing tumor cell plasticity in general. In normal tissues, plasticity is usually due to ability of SCs to change their positions through vertical up or down movements within tissue hierarchy (Batlle \& Clevers 2017). Recent advances in lineage tracing have revealed that plastic potential of tissue SCs is much greater and common than previously appreciated. In colonic epithelium, for example, secretory lineage cells or enterocytes can readily shift and replace SC niche upon loss of Lgr5 positive SC compartment (Tian et al. 2011, van Es et al. 2012, Tetteh et al. 2016). Other studies also put forward that upregulation of signaling pathways such as Notch and Wnt from neighboring cells are essential in maintaining a SC niche in colonic crypts (Sato et al. 2011). In a more recent study, it was also observed that Gli1 expressing stromal cells can also assist SC differentiation program through expression of Wnt ligands (Değirmenci et al. 2018). Therefore, neighboring Paneth cells or enterocytes are not the only factors in their confinement to SC like properties through widely enhancing plasticity within colonic epithelium. In other tissues like trachea and kidney epithelium, similar observations with lineage tracking showed that SC compartment can be 
compensated by the other cell within the same tissue (Rock et al. 2009, Kusaba et al. 2014). Consequently, mechanisms regulating trans-differentiation can quickly adapt different types of cells to changes in tissue microenvironment so that plasticity or stemness is not limited to a given niche (like SCs) but can also be activated in other cell types on a demand basis.

Like in normal SCs, plasticity is not the inherent property of CSCs in tumors. In other words, both CSCs and other tumor cells are plastic and make necessary phenotypic transitions upon activation under suitable environmental cues or signals. This phenomenon has been illustrated in different cancer models of breast, and colorectal cancers (Gupta et al. 2011, Schwitalla et al. 2013). The first studies were carried in breast cancer cell lines from which different cell populations of cells with SC, basal or luminal-like phenotypes were obtained. It was observed that all these cell populations were able to shift to other phenotypes and repopulate missing niches proportional to stochastic ratios found in the original cell line (Gupta et al. 2011). Regardless of these observations, only SC like cells showed tumorigenic abilities fitting to CSC definition. However, when the environmental cues were altered through co-culturing experiment, all these three cell populations could become equally tumorigenic to be able to form xenotransplants efficiently. Hence, we can conclude that breast cancer cells like in normal tissues are not fixed in certain niches and that they may change their phenotypic properties to adapt changing environmental signals to further tumor development.

\section{CSCs and Tumor Microenvironment}

Tumor microenvironment is very important in shaping tumor development and is the source for plasticity of tumor cells. Tumor microenvironment shapes every facet of the tumor cell plasticity through interactions between tumor cells in different populations and also their interplay with stromal and immune cells. Signaling machinery activated through interactions of these cells with each other and with the surrounding extracellular matrix (ECM) gives rise to spatiotemporal changes in stemness, de-/trans-differentiation and EMT programs to adapt tumor cells to differing conditions within tumor microenvironment (Göktuna et al. 2018). Many studies in colorectal cancer provided support for the importance of CSC functions in tumor cell plasticity. Since Wnt ligand expression in crypts is critical for sustaining an undifferentiated state in intestinal SCs (ISCs), most colorectal tumors are initiated upon constitutive Wnt activation which leads to a cryptic progenitor phenotype in resulting cancer cells. Consequently, supporting bottom-up hypothesis of colorectal tumorigenesis, Wntactivated ISCs were proposed to be the source of colorectal cancer and all the subpopulation of tumor clones should be coming from these progenitors (Barker et al. 2009).

Other studies in colorectal cancer models have suggested that non-CSCs can also form neoplastic growths just like their SC partners. In one such study, it was found that regardless of having the same activating mutations for Wnt signaling, tumorigenic ability of tumor cells was found to be affected by Wnt expression levels in each cell (Brabletz et al. 2001). Parallel to these observations, non-CSCs were observed to acquire tumorigenic and self-renewing abilities upon HGF signals from stromal cells (Vermeulen et al. 2010). Finally, in our previous work with Wnt-driven tumor models in mice, we have shown that top-down model of tumorigenesis where non-SCs can also generate neoplastic growths in tumor subclones was equally plausible (Schwitalla et al. 2013). During colorectal cancer initiation, active-NF-K $\mathrm{B}$ signaling can initiate a chronic inflammatory microenvironment which can trigger de-differentiation on non-SCs to a more SC like phenotype. In this study, we used an inducible Xbp1-Villin-Cre-ER ${ }^{\mathrm{T} 2}$ mediated activation of both Wnt $\left(\mathrm{Apc}^{\mathrm{fl} / \mathrm{fl}}\right)$ and $\mathrm{NF}_{-\mathrm{K}} \mathrm{B}\left(\mathrm{Ikba}^{\mathrm{fl} / \mathrm{fl}}\right)$ signaling specifically in differentiated cells which dedifferentiated into a SC like phenotype and promoted neoplastic growths up in the villi (Schwitalla et al. 2013). In another study, Elp3 signaling in Dclk1 ${ }^{+}$(Tuft cell specific marker) was found to be essential in maintaining Lgr5 $^{+}$CSC niche. Although Dclk1 was previously identified as a terminal differentiation marker and its absence had no observable phenotype in normal colonic epithelium, Dclk-Lgr $5^{+}$CSCs or organoids were observed to be largely lacking of regenerative and tumorigenic abilities (Ladang et al. 2015).

Studies with human colorectal organoids also further support the importance of the microenvironment driven plasticity in tumor development (Shimokawa et al. 2017, de Sousa e Melo et al. 2017). In one study with human colorectal cancer organoid xenografts, it was observed that human colorectal cancer cells can behave much similarly to tumor cells in mouse models. An inducible suicide gene (Casp9) was inserted into human colorectal organoids through CRISPR/Cas9 editing (Shimokawa et al. 2017). This inducible gene is activated selectively in Lgr5 $^{+}$cells so that SCs are totally eliminated and organoids halted growing. Upon removal of the inducer, organoids resumed growing from remaining terminally differentiated cells. Further studies revealed that terminally differentiated $\mathrm{Krt}^{2} \mathrm{O}^{+}$cells repopulated $\mathrm{Lgr}^{+}$ niche which supports tumorigenic phenotype in organoid xenotransplants (Shimokawa et al. 2017). In a similar study with diphtheria toxin induced Lgr5 ablation in human organoids, removal of diphtheria toxin resumed tumor growth in original tumor but not in distant metastases of the same tumor (de Sousa e Melo et al. 2017). Therefore, tumor microenvironment can affect plasticity differently in the original site and the metastatic colonies. However, in other cancers like glioblastoma, plasticity within cell populations was observed to be very limited and no replacement of CSCs niche by other cells was observed in a mouse model of glioblastoma (Suva $e t$ al. 2014). Therefore, the level of tumor cell plasticity varies greatly depending on the context, tissue of origin, 
site of growth and the interactions between different cells within the tumor microenvironment.

Signaling machinery activated through interaction within the tumor microenvironment is also very important for maintaining SC populations for further tumor growth. As tumor cells interact with each other to maintain selfrenewal and to enhance their tumorigenic potential, they also interact with other cell types within the tumor microenvironment. Previously, we mentioned about the importance of their interaction with stromal cells which help them to maintain stemness or de-differentiation (Değirmenci et al. 2018, Vermeulen et al. 2010). Inflammation in the tumor microenvironment is another important component of plasticity. Although we have mentioned that over-activated $\mathrm{NF}_{-\mathrm{K}} \mathrm{B}$ signaling is important for de-differentiation of non-SCs in tumors, hyper-activated $\mathrm{NF}_{-\mathrm{K}} \mathrm{B}$ signaling may also lead to myeloid specific anti-tumor response in a mouse model of $\mathrm{IKK}_{\mathrm{K}}$ specific ablation (Göktuna et al. 2014). Moreover, $\mathrm{IKK}_{\mathrm{K}}\left(\mathrm{NF}_{-\mathrm{K}} \mathrm{B}\right)$ ablation in tumor associated fibroblast potentiates them to secrete more HGF which was previously shown to be increasing de-differentiation into SC like phenotype in tumor cells (Pallangyo et al. 2015, Vermeulaen et al. 2010). Chronic inflammation can still benefit the tumor growth in a cell and context dependent manner as revealed by studies with $\mathrm{IKK}_{\mathrm{K}}$ or $\mathrm{IKK}_{\mathrm{K}}$ specific ablations in Wnt-driven models of tumorigenesis (Greten et al. 2004, Göktuna et al. 2016). All these findings illustrate that we urgently need to extend our understanding of tumor cell plasticity not only via tumor specific isolated model but also by finding ways to simulate complex interactions within the tumor microenvironment.

\section{CSCs and EMT}

When neoplastic growths reach to a certain size, their further expansion is usually restricted by the surrounding tissues and the basal lamina (Göktuna et al. 2018). Then it becomes increasingly difficult to keep the pace of the proliferation due to limiting factors like lack of space, nutrients, and oxygen supply. At this stage, epithelial to mesenchymal plasticity (EMP) helps tumor cells quickly adapt these new conditions, granting them the ability to shift their phenotypes from epithelial to mesenchymal for motility and invasion or back to epithelial phenotype for colonizing distant locations (Kalluri \& Weinberg 2009). Although EMT and mesenchymal to epithelial transition (MET) are natural processes during development, growth and wound healing mechanisms, tumor cell may hijack these machineries to provide themselves with many advantages. During the process of EMT, tumor cells constantly acquire new characteristics like anchorage independent growth, orchestrating immune or endothelial cells in immune tolerance or induction angiogenesis, matrix remodeling, vascularization to intravasate into the blood circulation (Kalluri \& Weinberg 2009). Most of these changes are related to mesenchymal phenotype since only fibroblast like cells can activate molecular pathways related to phenotypic changes in EMT through alteration of cytoskeleton dynamics and shifts in cell to cell or cell to ECM interactions (Friedl \& Alexander 2011). Although mesenchymal state is essential for invasion and motility, it is not suitable for the proliferation of the tumor cells (Mejlvang et al. 2007). Epithelial state, on the other hand, increases the efficiency of autocrine and paracrine growth signals due to the densely packed epithelia and helps rapid proliferation of tumor cells both in the primary and in metastatic growths. Therefore, EMP is essential for tumor cells to adapt and change their phenotypes depending on external signals and everchanging dynamics of the tumor microenvironment (Polyak \& Weinberg 2009).

As EMT is associated with migration, invasion, metastasis and chemotherapy resistance, it is not surprising that the relation between CSCs and EMT has been the focus of large amount of studies. As a result of such studies, it has been put forward that EMT also enhances stemness and tumor initiating potential in different cancer cell lines (Puisieux et al. 2014). More notably, tumor cells expressing high levels of EMT marker Snaill were found to have elevated tumor initiating and metastatic capabilities in mouse and human models of breast cancer (Ye et al. 2015). Initially, most of such observations were interpreted as the specific induction of EMT in CSC niche, yet later studies have clearly identified that CSCs just have different EMT programs than those operated in other tumor cells (Guo et al. 2012). Furthermore, many recent studies have demonstrated that metastatic cancer cells retain their epithelial phenotype in distant locations and even EMT may not be necessary for the metastasis altogether (Nieto et al. 2016, Zheng et al. 2015). Indeed, many reports support the notion that EMT repression is necessary for metastatic colonization as mesenchymal like cells were found not metastasizing efficiently (Celia-Terrassa et al. 2012, Tran et al. 2014, Tsai et al. 2012, Ocana et al. 2012). Additionally, intravital imaging in a mouse model of breast cancer confirmed previous claims with EMP as the tumor cells were observed to undergo MET upon metastasizing to distant organs (Beerling et al. 2016). Moreover, other studies have shown that Twist1 and Zeb1 expressions are differentially regulated during the course of tumor initiation, progression and metastasis and intermediary levels of these EMT regulators are required for tumor initiating CSC phenotypes in breast and skin cancers (Beck et al. 2015, Schmidt et al. 2015, Chaffer et al. 2016). Consequently, all the studies presented above have clearly demonstrated that CSC phenotypes are not fixed but highly plastic in nature and subject to change for adapting various conditions in the tumor microenvironment.

\section{Targeting CSCs for Cancer Therapy: Premises and Pitfalls}

Most of the chemotherapeutic strategies aiming to target highly proliferating cancer cells usually result in failure due to resistance development. As in many other cases of natural selection, surviving populations cause the 
relapse of the tumors with highly chemotherapy-resistant tumor cells (Holohan et al. 2010). In most cases, these chemotherapy-resistant cells are found to contain disproportionate fractions of CSCs (Batlle \& Clever 2017). Extraordinary chemo- or radiotherapy resistance in tumors may depend on diverse mechanisms provided by upregulation of drug-pumps, enhanced DNA-repair capacity or protection from stress mechanisms (genotoxic stress, ER stress or ROS) in CSCs (Li et al. 2008, Diehn et al. 2009, Borst et al. 2012). Notably, plasticity of CSCs (for tumor development and dissemination) and their ability to adopt a quiescent state (upon stressful conditions) drive drug resistance in many different cancers. Studies in hematologic malignancies have focused on associating hierarchical organization of tumor cells with the drug resistance development (Clarkson 1969). In some pioneering works with leukemia, it was observed that slowly proliferating SCs were the reason for tumor relapse (Clarkson \& Fried 1971). Later on, genetic fate mapping experiments in oxaliplatin resistant colorectal tumors demonstrated that tumor relapse after therapy is largely due to populations generated by quiescent CSCs (Kreso et al. 2013). Slowly proliferating CSCs in glioblastoma were found to be responsible for temozolomide resistance whereas ablation of these cells in tumors resensitizes glioblastoma to the drug (Chen et al. 2012). Similarly, cisplatin resistance results from slowly proliferating CSCs which found to show dormancy due to TGF $\square$ rich microenvironment in tumor fronts (Oshimori et al. 2015). Similar observations in models of bladder, breast and skin cancers also documented that slowly proliferating quiescent CSCs are the reason for drug resistance and tumor relapse after initially successful anti-proliferative therapy (Kurtova et al. 2015, Creighton et al. 2009). On the other hand, studies of tumor cell populations from highly proliferative tissues like stomach and intestine have demonstrated that SC pool can be regenerated from differentiated tumor cells after chemotherapy (Stange et al. 2013, Wei et al. 2016). As previously discussed in tumor cell plasticity, differentiated cells in various cancers may be acting as quiescent SCs to drive drug resistance in these cancers.

Understanding of drug resistance mechanisms due to CSCs provided us with better strategies to target tumors. The first successful story came from studies with leukemia which laid the foundation for using anti-CSC therapy in treating cancers (Novak et al. 2009). As we mentioned above, most leukemic cells are arrested in a quiescent undifferentiated state. Therefore, it was hypothesized that induction of terminal differentiation with all-trans retinoic acid could be beneficial for sensitizing tumors to chemotherapy. Results were massively successful and all-trans retinoic acid became the standard therapy for treating acute promyelocytic leukemia. The success of this strategy influenced many other studies in developing alternative ways to target CSCs in hematologic and solid malignancies. For example, targeting epigenetic regulators of stemness like
Lsd1 or Bmi1 were found to give favorable results abrogating CSC niches in AML or colorectal cancer models, respectively, without causing noticeable side effects (Harris et al. 2012, Kreso et al. 2014). Even some Lsd 1 inhibitors are currently in phase 2 clinical trials for treating AML. As previously mentioned, genetic ablation of CSCs in glioblastoma, squamous cell carcinoma and colorectal cancer prevents tumor growth (Chen et al. 2012, Boumadhi et al. 2014, Shimokawa et al. 2017). These studies are currently being tried for preclinical application. For instance, the use of Lgr5 antibody in combination with cytotoxic chemotherapy (in combination with cetuximab, an anti-EGFR antibody) yielded favorable results in colorectal cancer therapy (Shimokawa et al. 2017). Similarly, antibody-drug conjugates targeting Notch signaling successfully eliminated tumor initiating CSCs in a xenograft model of pulmonary neuroendocrine cancer (Yen et al. 2015; Saunders et al. 2015). Although above strategies exemplify successes in eliminating tumor initiating CSC, it is still a big challenge to target quiescent CSCs in drug resistance. However, in one study with chronic myelogenous leukemia (CML), ablation of quiescent state by targeting Myc inhibitor Fbxw7 rendered CML sensitive to imatinib (Takeishi et al. 2013). In a reverse strategy with a model of bladder cancer, Cox-2 inhibitors were used to block the entry of CSCs into a quiescent state which rendered them susceptible to chemotherapy (Kurtova et al. 2015). Targeting CSC metabolism also yielded fruitful results in abrogating chemoresistance in models of melanoma, pancreatic and oral cancers (Roesch et al. 2013, Viale et al. 2014, Pascual et al. 2017).

\section{Future Directions}

From the early observations of tumor development and dissemination, we started to notice that tumors are composed of cells of different hierarchies reminiscent of the organization in the normal tissues. Tumors from different cancers harbor self-renewing CSC niches which regenerate tumors or turn themselves into various other types of cells within the tumors. By applying the simple principles we have learned from normal SCs and by identifying tumor microenvironment dependent requirements of CSCs in each tissue and cancer separately, we can fashion better therapeutic strategies through modulating CSC behaviors in cancers.

In early studies, allografts and xenografts were crucial for understanding CSC behaviors in the tumors. However, with the advance of more powerful molecular and imaging techniques, lineage tracking became the standard for the identification of CSCs. Coupled to further developments in intra-vital imaging, high-end genome editing tools and the use of organoid models, we learned a great deal of CSC functions in tumor development and dissemination in many cancers. From these observations, we could deduce that SCs are not always rare, dormant or fixed to a certain niche. The great level of variability of CSCs is indeed due to the plasticity of the tumor cells 
which provides adaptation of tumors to constantly changing conditions within the tumor microenvironment. The tumor cell plasticity within tumors is forged through adaptations arising from mutations, EMT, and other interactions within the tumor microenvironment. Hence, inflammation and tumor to immune cell interactions are essential components of the mechanisms leading to plasticity.

While not all tumors in every cancer follow the CSC hierarchy or dynamics, there is a great level of plasticity between different populations of cells ultimately leading to great level of heterogeneity within tumors. Besides, the tumor cell plasticity brings about many challenges for our understanding of CSC in tumor development and dissemination. There are still many questions left to be answered by future studies. We still do not know how tumor cells define the CSC niche? We also do not know to which extent the tumor cell phenotypes within tumors can be switched? How do different states of tumor cells

\section{References}

1. Al-Hajj, M., Wicha, M.S., Benito-Hernandez, A., Morrison, S.J. \& Clarke, M.F. 2003. Prospective identification of tumorigenic breast cancer cells. Proceedings of the National Academy of Sciences of the United States of America, 100(7): 3983-3988.

2. Ball, C.R. Oppel, F., Ehrenberg, K.R., Dubash, T.D., Dieter, S.M., Hoffmann, C.M., Abel, U., Herbst, F., Koch, M., Werner, J., Bergmann, F., Ishaque, N., Schmidt, M., von Kalle, C., Scholl, C., Fröhling, S., Brors, B., Weichert, W., Weitz, J. \& Glimm, H. 2017. Succession of transiently active tumor-initiating cell clones in human pancreatic cancer xenografts. EMBO Molecular Medicine, 9(7): 918932.

3. Barker, N., van Es, J.H., Kuipers, J., Kujala, P., van den Born, M., Cozijnsen, M., Haegebarth, A., Korving, J., Begthel, H., Peters, P.J. \& Clevers, H. 2007. Identification of stem cells in small intestine and colon by marker gene Lgr5. Nature, 449: 1003-1007

4. Batlle, E. \& Clevers, H. 2017. Cancer stem cells revisited. Nature Medicine, 23(10): 1124-1134.

5. Beck, B. \& Blanpain, C. 2013. Unravelling cancer stem cell potential. Nature Reviews Cancer, 13(10): 727-738.

6. Beck, B., Lapouge G., Rorive, S., Drogat, B., Desaedelaere, K., Delafaille, S., Dubois, C., Salmon, I., Willekens, K., Marine, J.C. \& Blanpain, C. 2015. Different levels of Twist1 regulate skin tumor initiation, stemness, and progression. Cell Stem Cell, 16, 67-79.

7. Boiko, A.D., Razorenova, O.V., van de Rijn, M., Swetter, S.M., Johnson, D.L., Ly, D.P., Butler, P.D., Yang, G.P., Joshua, B., Kaplan, M.J., Longaker, M.T. \& Weissman, I.L. 2010. Human melanoma-initiating cells express neural crest nerve growth factor receptor CD271. Nature, 466(7302): 133-137.

8. Bonnet, D. \& Dick, J.E. 1997. Human acute myeloid leukemia is organized as a hierarchy that originates from a primitive hematopoietic cell. Nature Medicine, 3(7): 730737. affect basic mechanisms in tumor plasticity, EMT or therapy resistance? What are other factors regulating regeneration of lost CSC compartments in tumors? Even more complicatedly, CSC behaviors differ largely in their responses to produce therapy resistance in cancers. Therefore, to answer some of these questions more powerful techniques such as single cell sequencing and multiplexed MALDI-imaging analysis are required to map cell to cell interactions and hierarchical distributions in tumor and in surrounding tissues. The ultimate goal of these studies is to develop superior strategies to tackle cancer. To do so, we need to foster our knowledge on tumor development. Therefore, better understanding of the rules governing hierarchical distribution of the cells and their interactions within the tumor microenvironment will be crucial to reach this goal.

\section{Acknowledgement}

SİG is supported by TÜBA-GEBİP and Bilim Akademisi BAGEP fellowships.

9. Borst, P. 2012. Cancer drug pan-resistance: pumps, cancer stem cells, quiescence, epithelial to mesenchymal transition, blocked cell death pathways, persisters or what? Open Biology, 2(5): 120066.

10. Brabletz, T., Jung, A., Reu, S., Porzner, M., Hlubek, F., Kunz-Schughart, L.A., Knuechel, R. \& Kirchner, T. 2001. Variable beta-catenin expression in colorectal cancers indicates tumor progression driven by the tumor environment. Proceedings of the National Academy of Sciences of the United States of America, 98(18): 1035610361.

11. Celià-Terrassa, T., Meca-Cortés, O., Mateo, F., Martínez de Paz, A., Rubio, N., Arnal-Estapé, A., Ell, B.J., Bermudo, R., Díaz, A., Guerra-Rebollo, M., Lozano, J.J., Estarás, C., Ulloa, C., Álvarez-Simón, D., Milà, J., Vilella, R., Paciucci, R., Martínez-Balbás, M., de Herreros, A.G., Gomis, R.R., Kang, Y., Blanco, J., Fernández, P.L. \& Thomson, T.M. 2012. Epithelial-mesenchymal transition can suppress major attributes of human epithelial tumor-initiating cells. The Journal of Clinical Investigation, 122(5): 1849-1868.

12. Chaffer, C.L., Marjanovic, N.D., Lee, T., Bell, G., Kleer, C.G., Reinhardt, F., D'Alessio, A.C., Young, R.A. \& Weinberg, R.A. 2013. Poised chromatin at the ZEB1 promoter enables breast cancer cell plasticity and enhances tumorigenicity. Cell, 154(1): 61-74.

13. Chau, T.L., Gioia, R., Gatot, J.S., Patrascu, F., Carpentier, I., Chapelle, J.P., O'Neill, L., Beyaert, R., Piette, J. \& Chariot A. 2008. Are the IKKs and IKK-related kinases TBK1 and IKK-epsilon similarly activated? Trends in Biochemical Sciences, 33(4):171-180.

14. Chen, J., Li, Y., Yu, T., McKay, R.M., Burns, D.K., Kernie, S.G., \& Parada, L.F. 2012. A restricted cell population propagates glioblastoma growth after chemotherapy. Nature, 488(7412): 522-526.

15. Clarkson, B.D. 1969. Review of recent studies of cellular proliferation in acute leukemia. National Cancer Institute Monograph, 30: 81-120. 
16. Clarkson, B.D. \& Fried, J. 1971. Changing concepts of treatment in acute leukemia. The Medical Clinics of North America, 55(3): 561-600.

17. Clayton, E., Doupé, D.P., Klein, A.M., Winton, D.J., Simons, B.D. \& Jones, P.H. 2007. A single type of progenitor cell maintains normal epidermis. Nature, 446(7132): 185-189.

18. Clevers, H. 2011. The cancer stem cell: premises, promises and challenges. Nature Medicine, 17: 313-319.

19. Cortina, C., Turon, G., Stork, D., Hernando-Momblona, X., Sevillano, M., Aguilera, M., Tosi, S., Merlos-Suárez, A., Stephan-Otto Attolini, C., Sancho, E. \& Batlle, E. 2017. A genome editing approach to study cancer stem cells in human tumors. EMBO Molecular Medicine, 9(7): 869-879.

20. Degirmenci, B., Valenta, T., Dimitrieva, S., Hausmann, G. \& Basler, K. 2018. GLI1-expressing mesenchymal cells form the essential Wnt-secreting niche for colon stem cells. Nature, 558: 449-453.

21. Diehn, M., Cho, R.W., Lobo, N.A., Kalisky, T., Dorie, M.J., Kulp, A.N., Qian, D., Lam, J.S., Ailles, L.E., Wong, M., Joshua, B., Kaplan, M.J., Wapnir, I., Dirbas, F.M., Somlo, G., Garberoglio, C., Paz, B., Shen, J., Lau, S.K., Quake, S.R., Brown, J.M., Weissman, I.L. \& Clarke. M,F. 2009. Association of reactive oxygen species levels and radioresistance in cancer stem cells. Nature, 458(7239): 780-783.

22. de Sousa e Melo, F., Kurtova, A.V., Harnoss, J.M., Kljavin, N., Hoeck, J.D., Hung, J., Anderson, J.E., Storm, E.E., Modrusan, Z., Koeppen, H., Dijkgraaf, G.J., Piskol, R. \& de Sauvage, F.J. 2017. A distinct role for Lgr5+ stem cells in primary and metastatic colon cancer. Nature, 543: 676-680.

23. Doulatov, S., Notta, F., Laurenti, E. \& Dick, J.E. 2012 Hematopoiesis: a human perspective. Cell Stem Cell, 10 120-136.

24. Doupé, D.P., Klein, A.M., Simons, B.D. \& Jones, P.H. 2010. The ordered architecture of murine ear epidermis is maintained by progenitor cells with random fate. Developmental Cell, 18: 317-323.

25. Enderling, H., Hlatky, L. \& Hahnfeldt, P. 2013. Cancer Stem Cells: A minor cancer subpopulation that redefines global cancer features. Frontiers in Oncology, 3: 76.

26. Friedl, P. \& Alexander, S. 2011. Cancer invasion and the microenvironment: plasticity and reciprocity. Cell, 147(5): 992-1009.

27. Göktuna, S.I., Canli, Ö., Bollrath, J., Fingerle, A.A., Horst, D., Diamanti, M., Pallangyo, C., Bennecke, M., Nebelsiek, T., Mankan, A.K., Lang, R., Artis, D., Hu, Y., Patzelt, T., Ruland, J., Kirchner, T., Taketo, M.M., Chariot, A., Arkan, M.C. \& Greten, F.R. 2014. IKKalpha promotes intestinal tumorigenesis by limiting recruitment of M1-like polarized myeloid cells. Cell Reports, 7(6):1914-1925.

28. Göktuna, S.I., Shostak, K., Chau, T.L., Heukamp, L., Hennuy, B., Duong, H.Q., Ladang, A., Close, P., Klevernic, I., Olivier, F., Florin, A., Ehx, G., Baron, F., Vandereyken, M., Rahmouni, S., Vereecke, L., van Loo, G., Büttner, R., Greten, F.R. \& Chariot, A. 2016. The pro-survival IKK- related kinase IKKepsilon integrates LPS and IL-17A signaling cascades to promote Wnt-dependent tumor development in the intestine. Cancer Research, 76(9): 2587-2599.

29. Göktuna, S. I., Diamanti, M. A. \& Chau, T. L. 2018. IKKs and tumor cell plasticity. The FEBS Journal, 285: 21612181.

30. Greten, F., Eckmann, L., Greten, T., Park, J., Li, Z., Egan, L., Kagnoff, M. \& Karin, M. 2004. IKKbeta links inflammation and tumorigenesis in a mouse model of colitis-associated cancer. Cell. 118(3): 285-296.

31. Grompe, M. 2012. Tissue stem cells: New tools and functional diversity. Cell Stem Cell. 10: 685-689.

32. Guo, W., Keckesova, Z., Donaher, J.L., Shibue, T., Tischler, V., Reinhardt, F., Itzkovitz, S., Noske, A., ZürrerHärdi, U., Bell, G., Tam, W.L., Mani, S.A., van Oudenaarden, A. \& Weinberg, R.A. 2012. Slug and Sox9 cooperatively determine the mammary stem cell state. Cell, 148: 1015-1028.

33. Gupta, P.B., Fillmore, C.M., Jiang, G., Shapira, S.D., Tao, K., Kuperwasser, C. \& Lander, E.S. 2011. Stochastic state transitions give rise to phenotypic equilibrium in populations of cancer cells. Cell, 146: 633-644.

34. Holohan, C., Van Schaeybroeck, S., Longley, D.B. \& Johnston, P.G. 2013. Cancer drug resistance: an evolving paradigm. Nature Reviews Drug Discovery, 13: 714-726.

35. Hsu, Y.C., Li, L. \& Fuchs, E. 2014. Emerging interactions between skin stem cells and their niches. Nature Medicine, 20: $847-856$.

36. Kalluri, R. \& Weinberg, R.A. 2009. The basics of epithelial-mesenchymal transition. The Journal of Clinical Investigation, 119(6): 1420-1428.

37. Kelly, P.N., Dakic, A., Adams, J.M., Nutt, S.L. \& Strasser, A. 2007. Tumor growth need not be driven by rare cancer stem cells. Science, 317(5836): 337.

38. Kozar, S., Morrissey, E., Nicholson, A.M., van der Heijden, M., Zecchini, H.I., Kemp, R., Tavaré, S., Vermeulen, L. \& Winton, D.J. 2013. Continuous clonal labeling reveals small numbers of functional stem cells in intestinal crypts and adenomas. Cell Stem Cell, 13: 626-633.

39. Kretzschmar, K. \& Watt, F.M. 2012. Lineage tracing. Cell, 148(1-2): 33-45.

40. Kusaba, T., Lalli, M., Kramann, R., Kobayashi, A. \& Humphreys, B.D. 2014. Differentiated kidney epithelial cells repair injured proximal tubule. Proceedings of the National Academy of Sciences of the United States of America, 111: 1527-1532.

41. Ladang, A., Rapino, F., Heukamp, L. C., Tharun, L., Shostak, K., Hermand, D., Delaunay, S., Klevernic, I., Jiang, Z., Jacques, N., Jamart, D., Migeot, V., Florin, A., Göktuna, S., Malgrange, B., Sansom, O. J., Nguyen, L., Büttner, R., Close, P. \& Chariot, A. 2015. Elp3 drives Wntdependent tumor initiation and regeneration in the intestine. The Journal of Experimental Medicine, 212(12): $2057-$ 2075.

42. Lapidot, T., Sirard, C., Vormoor, J., Murdoch, B., Hoang, T., Caceres-Cortes, J., Minden, M., Paterson, B., Caligiuri, 
M.A. \& Dick, J.E. 1994. A cell initiating human acute myeloid leukaemia after transplantation into SCID mice. Nature, 367: 645-648.

43. Leushacke, M., Ng, A., Galle, J., Loeffler, M. \& Barker, N. 2013. Lgr5+ gastric stem cells divide symmetrically to effect epithelial homeostasis in the pylorus. Cell Reports, 5: 349-356.

44. Li, L., \& Bhatia, R. 2011. Stem cell quiescence. Clinical Cancer Research, 17(15): 4936-4941.

45. Li, X., Lewis, M.T., Huang, J., Gutierrez, C., Osborne, C.K., Wu, M.F., Hilsenbeck, S.G., Pavlick, A., Zhang, X., Chamness, G.C., Wong, H., Rosen, J. \& Chang, J.C. 2008. Intrinsic resistance of tumorigenic breast cancer cells to chemotherapy. Journal of the National Cancer Institute, 100: 672-679.

46. Magee, J.A., Piskounova, E. \& Morrison, S.J. 2012. Cancer stem cells: impact, heterogeneity, and uncertainty. Cancer Cell, 21(3): 283-296.

47. Marusyk, A., Almendro, V. \& Polyak, K. 2012. Intratumour heterogeneity: a looking glass for cancer? Nature Reviews Cancer, 12(5): 323-334.

48. Mejlvang, J., Kriajevska, M., Vandewalle, C., Chernova, T., Sayan, A.E., Berx, G., Mellon, J.K. \& Tulchinsky, E. 2007. Direct repression of cyclin D1 by SIP1 attenuates cell cycle progression in cells undergoing an epithelial mesenchymal transition. Molecular Biology of the Cell, 18(11): 4615-4624.

49. Merlos-Suárez, A., Barriga, F.M., Jung, P., Iglesias, M., Céspedes, M.V., Rossell, D., Sevillano, M., HernandoMomblona, X., da Silva-Diz, V., Muñoz, P., Clevers, H., Sancho, E., Mangues, R. \& Batlle, E. 2011. The intestinal stem cell signature identifies colorectal cancer stem cells and predicts disease relapse. Cell Stem Cell, 8: 511-524

50. Merrell A.J. \& Stanger, B.Z. 2016. Adult cell plasticity in vivo: de-differentiation and transdifferentiation are back in style. Nature Reviews Molecular Cell Biology, 17: 413425 .

51. Morizur, L., Chicheportiche, A., Gauthier, L. R., Daynac, M., Boussin, F. D., \& Mouthon, M. A. 2018. Distinct Molecular Signatures of Quiescent and Activated Adult neural stem cells reveal specific interactions with their microenvironment. Stem Cell Reports, 11(2): 565-577.

52. Morrison, S.J. \& Kimble, J. 2006. Asymmetric and symmetric stem-cell divisions in development and cancer. Nature. 441: 1068-1074.

53. Nassar, D. \& Blanpain, C. 2016. Cancer stem cells: basic concepts and therapeutic implications. Annual Reviews in Pathology, 11: 47-76.

54. Nieto, M.A., Huang, R.Y., Jackson, R.A. \& Thiery, J.P. 2016. EMT: 2016. Cell, 166, 21-45.

55. Novelli, M., Cossu, A., Oukrif, D., Quaglia, A., Lakhani, S., Poulsom, R., Sasieni, P., Carta, P., Contini, M., Pasca, A., Palmieri, G., Bodmer, W., Tanda, F. \& Wright, N. 2003. $\mathrm{X}$-inactivation patch size in human female tissue confounds the assessment of tumor clonality. Proceedings of the National Academy of Sciences of the United States of America, 100(6): 3311-3314.
56. Ocaña, O.H., Córcoles, R., Fabra, A., Moreno-Bueno, G., Acloque, H., Vega, S., Barrallo-Gimeno, A., Cano, A. \& Nieto, M.A. 2012. Metastatic colonization requires the repression of the epithelial-mesenchymal transition inducer Prrx1. Cancer Cell, 22: 709-724.

57. Oshimori, N., Oristian, D. \& Fuchs, E. 2015. TGF-b promotes heterogeneity and drug resistance in squamous cell carcinoma. Cell, 160: 963-976.

58. Pascual, G., Avgustinova, A., Mejetta, S., Martín, M., Castellanos, A., Attolini, C.S., Berenguer, A., Prats, N., Toll, A., Hueto, J.A., Bescós, C., Di Croce, L. \& Benitah, S.A. 2017. Targeting metastasis-initiating cells through the fatty acid receptor CD36. Nature, 541: 41-45.

59. Poltavets, V., Kochetkova, M., Pitson, S. M., \& Samuel, M. S. 2018. The role of the extracellular matrix and its molecular and cellular regulators in cancer cell plasticity. Frontiers in Oncology, 8: 431.

60. Polyak, K. \& Weinberg, R.A. 2009. Transitions between epithelial and mesenchymal states: acquisition of malignant and stem cell traits. Nature Reviews Cancer, 9(4): 265-273.

61. Puisieux, A., Brabletz, T. \& Caramel, J. 2014. Oncogenic roles of EMT-inducing transcription factors. Nature Cell Biology, 16: 488-494.

62. Quintana, E., Shackleton, M., Sabel, M. S., Fullen, D. R., Johnson, T. M., \& Morrison, S. J. 2008. Efficient tumour formation by single human melanoma cells. Nature, 456(7222): 593-598.

63. Radpour, R. 2017. Tracing and targeting cancer stem cells: New venture for personalized molecular cancer therapy. World Journal of Stem Cells, 9(10): 169-178.

64. Rangel-Huerta, E., \& Maldonado, E. 2017. Transitamplifying cells in the fast lane from stem cells towards differentiation. Stem Cells International, 7602951.

65. Rock, J.R., Onaitis, M.W., Rawlins, E.L., Lu, Y., Clark, C.P., Xue, Y., Randell, S.H. \& Hogan, B.L. 2009. Basal cells as stem cells of the mouse trachea and human airway epithelium. Proceedings of the National Academy of Sciences of the United States of America, 106: 1277112775.

66. Roerink, S.F., Sasaki, N., Lee-Six, H., Young, M.D., Alexandrov, L.B., Behjati, S., Mitchell, T.J., Grossmann, S., Lightfoot, H., Egan, D., Pronk, A., Smakman, N., van Gorp, J., Anderson, E., Gamble, S.J., Alder, C., van de Wetering, M., Campbell, P.J., Stratton, M.R. \& Clevers, H. 2018. Intra-tumour diversification in colorectal cancer at the single-cell level. Nature, 556: 457-462.

67. Roesch, A., Vultur, A., Bogeski, I., Wang, H., Zimmermann, K.M., Speicher, D., Körbel, C., Laschke, M.W., Gimotty, P.A., Philipp, S.E., Krause, E., Pätzold, S., Villanueva, J., Krepler, C., Fukunaga-Kalabis, M., Hoth, M., Bastian, B.C., Vogt, T. \& Herlyn, M. 2013. Overcoming intrinsic multidrug resistance in melanoma by blocking the mitochondrial respiratory chain of slowcycling JARID1B (high) cells. Cancer Cell, 23: 811-825.

68. Sato, T., van Es, J.H., Snippert, H.J., Stange, D.E., Vries, R.G., van den Born, M., Barker, N., Shroyer, N.F., van de Wetering, M. \& Clevers H. 2011. Paneth cells constitute the niche for Lgr5 stem cells in intestinal crypts. Nature, 469: 415-418. 
69. Saunders, L.R., Bankovich, A.J., Anderson, W.C., Aujay, M.A., Bheddah, S., Black, K., Desai, R., Escarpe, P.A., Hampl, J., Laysang, A., Liu, D., Lopez-Molina, J., Milton, M., Park, A., Pysz, M.A., Shao, H., Slingerland, B., Torgov, M., Williams, S.A., Foord, O., Howard, P., Jassem, J., Badzio, A., Czapiewski, P., Harpole, D.H., Dowlati, A., Massion, P.P., Travis, W.D., Pietanza, M.C., Poirier, J.T., Rudin, C.M., Stull, R.A. \& Dylla, S.J. 2015. A DLL3targeted antibody-drug conjugate eradicates high-grade pulmonary neuroendocrine tumor-initiating cells in vivo. Science Translational Medicine, 7: 302ra136.

70. Schatton, T., Murphy, G. F., Frank, N. Y., Yamaura, K., Waaga-Gasser, A. M., Gasser, M., Zhan, Q., Jordan, S., Duncan, L. M., Weishaupt, C., Fuhlbrigge, R. C., Kupper, T. S., Sayegh, M. H. \& Frank, M.H. 2008. Identification of cells initiating human melanomas. Nature, 451(7176): 345349.

71. Schepers, A.G., Snippert, H.J., Stange, D.E., van den Born, M., van Es, J.H., van de Wetering, M. \& Clevers, H. 2012. Lineage tracing reveals $\mathrm{Lgr}^{+}$stem cell activity in mouse intestinal adenomas. Science, 337: 730-735

72. Schmidt, J.M., Panzilius, E., Bartsch, H.S., Irmler, M., Beckers, J., Kari, V., Linnemann, J.R., Dragoi, D., Hirschi, B., Kloos, U.J., Sass, S., Theis, F., Kahlert, S., Johnsen, S.A., Sotlar, K. \& Scheel, C.H. 2015. Stem-cell-like properties and epithelial plasticity arise as stable traits after transient Twist1 activation. Cell Reports, 10: 131-139

73. Schwitalla, S., Fingerle, A.A., Cammareri, P., Nebelsiek, T., Göktuna, S.I., Ziegler, P.K., Canli, O., Heijmans, J., Huels, D.J., Moreaux, G., Rupec, R.A., Gerhard, M., Schmid, R.M., Barker, N., Clevers, H., Lang, R., Neumann, J., Kirchner, T., Taketo, M.M., van den Brink, G.R., Sansom, O.J., Arkan, M.C. \& Greten, F.R. 2013. Intestinal tumorigenesis initiated by dedifferentiation and acquisition of stem-cell-like properties. Cell, 152: 25-38.

74. Shimokawa M., Ohta, Y., Nishikori, S., Matano, M., Takano, A., Fujii, M., Date, S., Sugimoto, S., Kanai, T. \& Sato, T. 2017. Visualization and targeting of LGR5 ${ }^{+}$ human colon cancer stem cells. Nature, 545: 187-192.

75. Snippert, H.J., van der Flier, L.G., Sato, T., van Es, J.H., van den Born, M., Kroon-Veenboer, C., Barker, N., Klein, A.M., van Rheenen, J., Simons, B.D. \& Clevers, H. 2010. Intestinal crypt homeostasis results from neutral competition between symmetrically dividing Lgr5 stem cells. Cell, 143: 134-144.

76. Stange, D.E., Koo, B.K., Huch, M., Sibbel, G., Basak, O., Lyubimova, A., Kujala, P., Bartfeld, S., Koster, J., Geahlen, J.H., Peters, P.J., van Es, J.H., van de Wetering, M., Mills, J.C. \& Clevers, H. 2013. Differentiated Troy+ chief cells act as reserve stem cells to generate all lineages of the stomach epithelium. Cell, 155: 357-368.

77. Stanger, B.Z. 2015. Cellular homeostasis and repair in the mammalian liver. Annual Reviews in Physiology, 77: 179200.

78. Takeishi, S., Matsumoto, A., Onoyama, I., Naka, K., Hirao, A. \& Nakayama, K.I. 2013. Ablation of Fbxw7 eliminates leukemia-initiating cells by preventing quiescence. Cancer Cell, 23: 347-361.
79. Teng, Y.D., Wang, L., Kabatas, S., Ulrich, H., Zafonte, R.D. 2018. Cancer stem cells or tumor survival cells? Stem Cells Development, 27(21): 1466-1478.

80. Tetteh, P.W., Basak, O., Farin, H.F., Wiebrands, K., Kretzschmar, K., Begthel, H., van den Born, M., Korving, J., de Sauvage, F., van Es, J.H., van Oudenaarden, A. \& Clevers, H. 2016. Replacement of lost Lgr5-positive stem cells through plasticity of their enterocyte-lineage daughters. Cell Stem Cell, 18: 203-213.

81. Tian, H., Biehs, B., Warming, S., Leong, K.G., Rangell, L., Klein, O.D. \& de Sauvage, F.J. 2011. A reserve stem cell population in small intestine renders Lgr5-positive cells dispensable. Nature, 478: 255-259.

82. Tran, H.D., Luitel, K., Kim, M., Zhang, K., Longmore, G.D. \& Tran, D.D. 2014. Transient SNAIL1 expression is necessary for metastatic competence in breast cancer. Cancer Research, 74: 6330-6340.

83. Tsai, J.H., Donaher, J.L., Murphy, D.A., Chau, S. \& Yang, J. 2012. Spatiotemporal regulation of epithelialmesenchymal transition is essential for squamous cell carcinoma metastasis. Cancer Cell, 22: 725-736.

84. van Es, J.H., Sato, T., van de Wetering, M., Lyubimova, A., Yee Nee, A.N., Gregorieff, A., Sasaki, N., Zeinstra, L., van den Born, M., Korving, J., Martens, A.C.M., Barker, N., van Oudenaarden, A. \& Clevers, H. 2012. Dll1+ secretory progenitor cells revert to stem cells upon crypt damage. Nature Cell Biology, 14: 1099-1104.

85. Vermeulen, L., De Sousa E Melo, F., van der Heijden, M., Cameron, K., de Jong, J.H., Borovski, T., Tuynman, J.B., Todaro, M., Merz, C., Rodermond, H., Sprick, M.R., Kemper, K., Richel, D.J., Stassi, G. \& Medema, J.P. 2010. Wnt activity defines colon cancer stem cells and is regulated by the microenvironment. Nature Cell Biology, 12: 468-476.

86. Viale, A., Pettazzoni, P., Lyssiotis, C.A., Ying, H., Sánchez, N., Marchesini, M., Carugo, A., Green, T., Seth, S., Giuliani, V., Kost-Alimova, M., Muller, F., Colla, S., Nezi, L., Genovese, G., Deem, A.K., Kapoor, A., Yao, W., Brunetto, E., Kang, Y., Yuan, M., Asara, J.M., Wang, Y.A., Heffernan, T.P., Kimmelman, A.C., Wang, H., Fleming, J.B., Cantley, L.C., DePinho, R.A. \& Draetta, G.F. 2014. Oncogene ablation-resistant pancreatic cancer cells depend on mitochondrial function. Nature, 514: 628-632.

87. Wei, L., Leibowitz, B.J., Wang, X., Epperly, M., Greenberger, J., Zhang, L. \& Yu, J. 2016. Inhibition of CDK4/6 protects against radiation-induced intestinal injury in mice. Journal of Clinical Investigations, 126: 40764087.

88. Weinberg, R. 2013. Chapter 11: Multistep Tumorigenesis, pp. 439-509. In: Molecular Biology of the Cancer. $2^{\text {nd }}$ Edition. Garland Science. New York.

89. Williams, R.T., den Besten, W. \& Sherr, C.J. 2007. Cytokine-dependent imatinib resistance in mouse BCRABL+, Arf-null lymphoblastic leukemia. Genes and Development, 21: 2283-2287.

90. Ye, X., Tam, W.L., Shibue, T., Kaygusuz, Y., Reinhardt, F., Ng Eaton, E. \& Weinberg, R.A. 2015. Distinct EMT programs control normal mammary stem cells and tumourinitiating cells. Nature, 525: 256-260. 
91. Yen, W.C., Fischer, M.M., Axelrod, F., Bond, C., Cain, J., Cancilla, B., Henner, W.R., Meisner, R., Sato, A., Shah, J., Tang, T., Wallace, B., Wang, M., Zhang, C., Kapoun, A.M., Lewicki, J., Gurney, A. \& Hoey, T. 2015. Targeting Notch signaling with a Notch2/Notch3 antagonist (tarextumab) inhibits tumor growth and decreases tumorinitiating cell frequency. Clinical Cancer Research, 21: 2084-2095.

92. Zhang, C.L., Huang, T., Wu, B.L., He, W.X. \& Liu, D. 2017. Stem cells in cancer therapy: opportunities and challenges. Oncotarget, 8(43): 75756-75766.
93. Zheng, X, Carstens, J.L., Kim, J., Scheible, M., Kaye, J., Sugimoto, H., Wu, C.C., LeBleu, V.S. \& Kalluri, R. 2015. Epithelial-to-mesenchymal transition is dispensable for metastasis but induces chemoresistance in pancreatic cancer. Nature, 527(7579): 525-530.

94. Zomer, A., Ellenbroek, S.I., Ritsma, L., Beerling, E., Vrisekoop, N. \& Van Rheenen, J. 2013. Intravital imaging of cancer stem cell plasticity in mammary tumors. Stem Cells, 31: 602-606. 